\title{
Questions Related to the Temporality of Minority Languages and Linguistic Varieties
}

\author{
Dr Servais Martial Akpaca \\ Department of English \\ Translation Studies Unit \\ Université d'Abomey-Calavi, Benin
}

\begin{abstract}
The aim of this paper is to discuss the concept of minority languages and the time when they started emerging in translation. Indeed, minority languages became a central issue at the end of the colonial era thanks to a number of institutional policies and political movements aimed at giving a voice to people who did not have a say for a number of reasons. The growing interest in these minority languages opened up a new avenue in terms of cultural exchanges and representation in translation. Nowadays translators have to cope with what some authors have rightly called the cultural turn which exposes them to a multiplicity of international human and social experience evolving across continents. Michael Cronin, Susan Bassnett and other authors have admitted that translators mediate through cultures and languages. Furthermore, the languages of the former colonisers, i.e. English and French, have also been the subject of variations in the sense that new world views, idioms, phrases, proverbs and uses have emerged here and there in both Anglophone and Francophone countries and translators are constantly called upon to give them a "new life in another language and culture". The methodology of the paper is both descriptive and analytical. In this logic, examples of "different" uses of both English and French in linguistic practices overseas will be given and analysed from cultural, temporal, social, philosophical, stylistic, semantic and lexical points of view. As a result, linguistic varieties and transformations have created a new situation whereby the languages of the former colonisers are just like "variables" with many "variants" around the globe. Two dimensions of translation, i.e. intra-lingual and extra-lingual translation, come into play. From another point of view, ethnic minority groups, the youth and immigrants also contribute to broadening the scope of minority languages and linguistic varieties.
\end{abstract}

Keywords: minority languages, culture, world view, extra-lingual translation, intra-lingual translation

\section{Introduction}

No discussion on minority languages and linguistic varieties can take place if the social or sociological context that plays host to language is abstracted. Language is a social construct and a discussion of this type can only be placed in the perspective of sociolinguistics which Dubois, Giacomo et al. (2002: 435-436) define as follows:

La sociolinguistique est une partie de la linguistique dont le domaine se recoupe avec ceux de l'ethnolinguistique, de la sociologie du langage, de la géographie linguistique et de la dialectologie. La sociolinguistique se fixe comme tâche de faire apparaître dans la mesure du possible la covariance des phénomènes linguistique et sociaux et, éventuellement, d'établir une relation de cause à effet... La sociolinguistique peut prendre en considération comme donnée sociale l'état de l'émetteur (origine ethnique, profession, niveau de vie, etc.) et rattacher à cet état le modèle de performance dégagé... L'examen des variations géographiques de la langue n'est qu'un cas particulier de la sociolinguistique, quoique souvent on désigne cette recherche sous des dénominations particulières (dialectologie, géographie linguistique).

It emerges from this definition that sociolinguistics is part of linguistics and its research area cuts across ethnolinguistics, sociology of language, dialectology and linguistic geography. It studies social and linguistic phenomena as they co-occur, and establishes a causal relationship between them. This definition is likely to take us far in the exploration of the aspects of this topic, especially when it comes to issues pertaining to the diachronic and spatial nature of minority languages, intralingual and interlingual translation, dialectology, etc. Equally important in the definition is the concept of linguistic geography that should be regarded as an overarching notion which transcends continental borders and encompasses new and alien idioms, cultures and languages. On this score, Jacquemond (1992: 140) has noted that:

Because translation theory [...] has developed on the basis of the European linguistic and cultural experience, it relies on the implicit postulate of an egalitarian relationship between different linguistic and cultural areas and has yet to integrate the recent results of the sociology of interculturality in the colonial and postcolonial contexts. This quotation underlines the need to include in the translation theory the wealth of knowledge and experience available in languages and cultures that have been marginalised up to now for one reason or another. 
It is a truism that throughout the history of humanity, translation has been instrumental in importing ideas and precious knowledge from one language into another. It has greatly contributed to the progress of humanity and science because knowledgeable people who believe that every culture has something special to share with the rest of the world have placed a premium on intercultural exchanges and communication. Even today the world depends on the flow of information and knowledge from source languages to target languages. That notwithstanding, minority languages situated overseas also have something to offer. In the same vein, Lane, Costa and De Korne (2018: 9) have pointed out that:

In contrast, communities situated in colonially constructed nations are not always geographically peripheral nor a numerical minority. However, they are routinely excluded from official and prestigious social spaces, and their ways of communicating are marginalised relative to colonial languages, as exemplified in the cases of Manding across West Africa (see Donaldson, this volume), isiXhosa in South Africa (see Deumert and Mabandla, this volume) or even perhaps of Scots speakers in Scotland (see Costa, this volume).

The exclusion of minority groups together with their languages became a matter of concern after World War II when they started agitating and demanding the recognition of their languages and cultures. Though it cannot be said that there is total recognition as at now, it is important to stress that minority languages and communities have become entities that should be reckoned with.

This paper endeavours to account for the dynamic nature of the concept of minority in the field of language. It tries to hammer home the idea that no language is essentially a minority language because minority is the expression of a power relation between languages. This discussion on minority languages and linguistic varieties is conducted in the perspective of translation. On this score, Bandia (2000: 266) has noted that:

Minority translating practices are highly inventive and can thus destabilize the dominant language by enhancing linguistic multiplicity and hybridity. Keith Harvey argues that translating in any cultural or political context can either be majoritarian or minoritarian as translation becomes a form of rewriting of the foreign text to conform to, or support, the dominant values in the translating culture.

Consequently the concepts of minority translating, linguistic multiplicity, dominant language, hybridity, etc., are going to be discussed in the current context of globalisation characterised by the dominant position of English and the instrumental role played by translation. In the following section, a definition of minority language is given to take us a step further in the discussion.

\section{Definition of minority language, its determinants and the historical background to the emergence of minority groups}

\section{I.1 Definition of minority language}

This concept is going to be defined and explained in the context of the historical experience of a language (i.e. Irish) that used to be a majority language, however due to political and social changes, it lost its majority status and became a minority language. As Leersen has explained:

The concept of "minority" with respect to language is dynamic rather than static. "Minority" is the expression of a relation not an essence. The relations can assume two forms: diachronic and spatial. The diachronic relation that defines a minority language is an historical experience that destabilises the linguistic relations in one country so that languages find themselves in an asymmetrical relationship. In the case of Ireland, English was a minority language for centuries (Seymour, 1929). The ascendancy of the English language did not begin until the sixteenth and seventeenth century with Tudor and Cromwellian expansionist policies which sought not only the military but also the cultural and linguistic submission of the native Irish (Leersen, 1986, p. 292).

According to this quotation, the majority status of the English language in Ireland today has not been static because it used to be a minority language in that country. On the contrary Irish, which is now a minority language in Ireland, used to be the majority language until the sixteenth and seventeenth century. The historical context that brought about the change of status of both languages has been described by Cronin in the following terms:

Military, social and economic forces, notably the Great Famine of the 1840s where Ireland lost half its mainly Irish- speaking population through starvation and emigration (Kallen, 1993, pp. 100-114), led to the erosion of the Irish language and the massive language-shift to English in the nineteenth-century (de Freine). Therefore, the position of the language changed from majority to minority status as a result of political developments over time. (1995: 86)

The case of Irish was an example of diachronic power relation between two languages. As announced earlier, the relation can also be spatial. An example of spatial relation is as follows: "Russian has now become a minority language in most of the Baltic Republics with the break-up of the Soviet Union. The change in borders left Russian speakers outside the State where Russian is the majority language." (Ibid: 87) 
In the case of Irish, the change of status occurred in the country where the language had a majority status but in the case of Russian, the change of status occurred outside the country where the language has the majority status. Cronin (Ibid) stresses that "The spatial/diachronic distinction is useful in evaluating the radically different contexts in which minority languages operate from the perspective of translation." Louis Wirth has also explained that a minority group is a group that has been cast aside by a dominant group or a group that regards itself as different from another larger group. Minority is not solely related to the number of people speaking the same language; it is also related to the positioning of groups within a social hierarchy.

Louis Wirth (1945) characterised minority groups both as being cast aside by a dominant group for being separate or different (in terms of customs, language or institutions) and as being viewed as different by its own members with respect to that same dominant group... In other words, minority or minoritised language is not used as a term based solely on the number of speakers, amount of territory or frequency of use; rather, dominance or minority status is attributed on the social positioning of groups within a hierarchical social structure (Patrick 2012). Thus, the concept of minority or minoritised language is an expression of relations among groups and not an inherent or essential quality of a language or group (Cronin 1995; Pietikainen, Huss, Laihiala-Kankainen, Aikio-Puoskari and Lane 2010). (Lane, Costa, and De Korne, 2018: 8)

In addition to the fact that minority language is not an inherent or essential quality, it is worth pointing out that its determinants are not solely diachronic or spatial. That is the point that is going to be discussed in the next section.

\section{I.2 New Determinants of a minority/majority language status}

Cronin has pointed out that technology is changing the definition of minority language by introducing translation differentials that can be classified into intralingual differentials and interlingual differentials. In the following quotation, he has explained what these terms mean.

Technology is changing our definition of the minority language. The language of the software utilities, the compact discs and the documentation are generating what might be termed translation differentials. These differentials can be classified into two broad types, intralingual translation differentials and interlingual translation differentials. An example of an intralingual translation differential would be the relationship between British and American English. The grammar and spell checkers, the on-line dictionaries and thesauruses, the synthesised voices produced by sound cards in multimedia upgrade kits, the reference material in atlases and encyclopedias that can be accessed on compact discs like Microsoft Bookshelf are overwhelmingly North American in orientation. (Ibid: 96-97)

Therefore, intralingual translation differentials hinge on the differences between British English and American English in terms of spelling, grammar, accents, cultural references, etc. Regarding the interlingual differential, Cronin (Ibid: 97-98) has made the following remark:

The interlingual translation differential is more apparent as languages other than English try to make software resources available to the non-Anglophone world. Software localisation is a significant growth area in translation but questions of intertextuality also need to be addressed if languages are not to find themselves with material that though translated reflects the cultural preoccupations and historical experiences of a different language and set of speakers... Developments in informatics, multimedia, MT and the Internet have translation implications insofar as they create their own translation imperatives. The differentials mentioned above mean that a language's status is always provisional and that changes in technology, for example, can result in it becoming a minority language that is SL intensive as it imports more and more material into the language. In the next section, the historical context in which minority groups emerged is going to be recalled.

\section{I.3 The historical context of the emergence of minority groups}

Lane, Costa and De Korne have explained in a paper entitled "Standardizing Minority Languages" that minority groups were recognised after World War II thanks to decolonial processes and international human rights conventions including:

The International Labour Organisation Convention 169 on Indigenous and Tribal Peoples (1989), the UN Declaration on the Rights of Persons Belonging to National or Ethnic, Religious and Linguistic Minorities (1992), and the UN Declaration on the Rights of Indigenous Peoples (2007), the Universal Declaration of Linguistic Rights (1996), the Charter for Regional and Minority Languages in 1992. On a national scale, some countries have implemented their own policies of recognition such as the Sami Language Act in Norway (1987), the postapartheid South African constitution (1996) and the Mexican Law on the Linguistic Rights of Indigenous Peoples (2003), among many others. (2018: 10)

Generally these conventions and charters recognise the aspirations of these peoples to exercise control over their own institutions, ways of life and economic development and to maintain and develop their identities, languages and religions, within the framework of the States in which they live. 
They call on governments to assume responsibility for developing, with the participation of the peoples concerned, co-ordinated and systematic action to protect the rights of these peoples and to guarantee respect for their integrity. For examples, the actions called for by ILO Convention 169 include: "ensuring that members of these peoples benefit on an equal footing from the rights and opportunities which national laws and regulations grant to other members of the population; promoting the full realisation of the social, economic and cultural rights of these peoples with respect for their social and cultural identity, their customs and traditions and their institutions; assisting the members of the peoples concerned to eliminate socio-economic gaps that may exist between indigenous and other members of the national community, in a manner compatible with their aspirations and ways of life."

Minority language and linguistic varieties are the two issues this paper is focusing on but so far only minority language and groups have been dealt with. In the next section, linguistic varieties will be discussed.

\section{Examples of linguistic varieties in the Anglophone and the Francophone spheres in Africa and beyond II.1 The case of Pidgin in Nigeria}

The Oxford Advanced Learner's Dictionary of Current English (1995: 871) defines the word pidgin as follows: "Any of several languages resulting from contact between Europeans and local peoples, esp. in West Africa and South East Asia, containing elements of the local language and especially English, French or Dutch." In Nigeria, Pidgin English is a very popular language that has its own grammar and vocabulary. The following is a Pidgin English song that shows how the sentences are formed in this language that borrows a lot from English. The title of the song is Sweet Mother by Prince Nico Mbarga

\section{Table 1: Sweet Mother}

\begin{tabular}{|l|l|}
\hline Pidgin & English \\
\hline Sweet mother I no go forget you & Sweet mother I won't forget you \\
For dey suffer wey you suffer for me yeah [2x] & Because of the way you suffer for me yeah [2x] \\
When i dey cry my mother go carry me & When I cry, my mother carries me \\
She go say my pikin wetin you dey cry yeah yeah & She says my baby why are you crying? \\
Stop stop! stop stop!! stop stop!!! & Stop stop! Stop stop!! Stop stop!!! \\
Make you no cry again oo & Don't cry again, please. \\
When i wan sleep my mother go pet me & When I want to sleep, my mother picks me. \\
She go lie me well-well for bed & She lays me well in bed. \\
She go cover me cloth say make you sleep & She covers me with a cloth and says 'sleep well'. \\
Sleep sleep my pikin oooo & Sleep, sleep, my darling, please. \\
When i dey hungry my mom go run up and down & When I am hungry, my mom runs up and down. \\
She dey find me somthing we i go chop & She finds me something to eat. \\
Sweet mother eeeee...sweet mother oooo..eee & Sweet mother eeeeee...sweet mother oooo...eee \\
When i dey sick my mother go cry cry cry & When I am sick, my mother cries all the time. \\
She go say instead wey i go die make she die & She says she'd rather die instead of me dying. \\
She go beg God, God help me, God help me, my & She begs God, God help me! God help me! My \\
pikin oo & darling, please. \\
If i no sleep, my mother no go sleep & If I don't sleep, my mother wouldn't sleep. \\
If i no chop, my mother no go chop & If I don't eat, my mother wouldn't eat. \\
She no dey tire ooo & She is never tired of me. \\
Sweet mother i no go forget dey suffer wey you... & Sweet mother I won't forget the way you suffer. \\
Source: https://genius.com/Prince-nico-mbarga- & \\
\hline sweet-mother-lyrics & \\
\hline
\end{tabular}

It is clear that the syntax and the grammar of this song are awkward from the point of view of an English speaker. A discussion will be made on these aspects at a later stage. In the francophone sphere, there is also a feeling of linguistic insecurity which is characterised by the introduction of local African words and expressions in African novels written in French as well as by the use of African languages' syntax, the influence of oral narrative tradition, a mixture of language registers, etc. In a paper titled «Appropriation, déconstruction du français et insécurité linguistique dans la littérature africaine d'expression française », Biloa (2007), has explained how African novelists have been using the French language in a way that deconstructs it and creates a sense of linguistic insecurity on the part of both the writer and the reader.

Les écritures littéraires africaines d'expression française se caractérisent par un certain nombre de spécificités qui sont la marque de l'appropriation de la langue française par les auteurs négro-africains : introduction des mots, des expressions, d'une syntaxe et d'un rythme nouveaux ; influence de l'oralité ; interférences des langues africaines ; surcharge de la culture noire ; réaménagement des stratégies discursives ; 
mélange des niveaux de langues ; éclatement, explosion, déconstruction et réinvention de la langue française. Pius Ngandu Nkashama (1989) disserte sur une des périodes qui « est surtout celle du déchirement. (Biloa, $2007: 109)$

Furthermore, Biloa comments that the concept of déchirement expressed by Pius Ngandu Nkashama is translated into French by incomprehensible words and expressions which are responsible for the feeling of linguistic insecurity.

La violence et le déchirement dans le langage dont parle Pius Ngandu Nkashama se traduisent parfois par des termes ou des expressions incompréhensibles aussi bien pour le lecteur que pour l'auteur qui se voit obligé de les expliquer (ou expliciter) soit dans le texte par des mises en apposition, soit dans des notes infrapaginales. Le manque de lisibilité de certains mots ou de certaines structures génère des sentiments d'insécurité linguistique de la part du lectorat et de celle de l'autorat. (Ibid : 109-110)

To illustrate his comments on this trend, which was set by Ahmadou Kourouma in Les Soleils des indépendances (1968), Biloa has given the following examples taken from Kourouma's novels: « Il y avait une semaine qu'avait fini dans la capitale Koné Ibrahim... » - comme si le verbe finir était désormais employé dans un emploi absolu pour signifier « mourir». (Ibid : 111) Equally conspicuous in the novels are strange expressions and coinage including: «contrebander, un vidé, un assis, coucher sa favorite, courber la prière, tuer un sacrifice, etc. Tous ces artifices témoignent de sa volonté de couler le malinké dans le moule français ou vice-versa». (Ibid)

So far an effort has been made to define the concepts of minority language and linguistic varieties and to recall the historical circumstances under which minority groups emerged. It is important at this stage to state the problem that this paper sets out to deal with and to indicate the research methodology.

\section{Problem statement and method}

\section{III.1 Problem statement}

This paper sets out to explore the contribution of minority languages and linguistic varieties to translation. It starts out on the point that the translation of knowledge and information from minority languages into dominant ones and vice-versa expands and develops the cultural heritage of humanity. Another issue that is equally important is a purely linguistic question, i.e. do minority languages teach linguists anything new? The impact of linguistic varieties like Pidgin English on Standard English is also going to be discussed together with issues pertaining to the role played by translation in the global positioning of languages today. In other words, has translation become a yardstick by means of which the importance of languages can be assessed in the world today? These are some of the issues that this paper aims to discuss in the following sections. To achieve this end, the research methodology needs to be specified.

\section{III.2 Research method}

In translating the Sweet Mother song from Pidgin into English, differences related to syntax, lexical items and grammar have been noted. On the strength of this example and others that are going to be given, it is right to state that the research method is descriptive and analytical. Another approach that this paper is going to adopt is comparative. Indeed, several languages are going to be compared in a bid to determine whether they are SL language intensive or TL language intensive. Obviously this comparison has implications as to whether or not a particular language is a minority language or a majority language given that when the translation traffic from a language A to a language B is too heavy and almost entirely unidirectional, language B is most likely a minority language. Having mentioned the problem statement and the research method, this paper will now proceed to reveal the research results before discussing them at a later stage.

\section{Results}

Research result 1: Minority translating submits the majority language to variation and exposes the target culture to the influence of the source culture. Research result 2: Just like Cronin, this paper stresses that languages and political circumstances change. The majority status of a language is determined by political, economic and cultural forces that are rarely static and therefore all languages are potentially minority languages.

Research result 3: Following Cronin's remarks, this paper attests that languages can be divided into those languages which are target-language intensive and those languages which are source-language intensive. An example of a TL intensive language would be English where there is intense translation activity from English into other languages but where there is markedly less translation traffic in the opposite direction (Jacquemond, 1992, pp. 139-140).

Research result 4: Another factor that informs the relational position of minority languages is the fact that it is precisely the pressure to translate that is a central rather than a peripheral aspect of experience. 
Research result 5: Major language culture is informed by the minority language in translation (e.g. in the area of song, modes of intention, semantic fields, national identity).

Research result 6: Translation theory itself remains hostage to the perceptions and interests of major languages. Cronin, 94)

Research result 7: The information and communication technologies are changing the definition of minority languages by favouring the development of new linguistic varieties.

Research result 8: No conformity of some literary productions with grammatical and academic standards due to a new linguistic phenomenon called "nationalisme glottocentrique". These results are going to be discussed in the next section that will provide examples and justifications.

\section{Discussion}

According to research result 1, minority translating submits the majority language to variation and exposes the target culture to the influence of the source culture. Indeed, the way English and French are written and spoken in Africa and in other parts of the world is not exactly the same as in Europe. African writers, e.g., use local proverbs and expressions in their novels and translations. Variation in this case should not simply be limited to lexical considerations. When a translator has to translate the following proverbs by Achebe, s/he should not only translate the words but $\mathrm{s} / \mathrm{she}$ should try and understand the meaning of the proverbs first. "Our elders say that the sun will shine on those who stand before it shines on those who kneel under them." What does that mean? That is the first question a careful translator will ask. Another proverb by Achebe says that "If a child washed his hands, he could eat with kings." This calls for the introduction of sociology courses in translation studies. This point is supported by the following remark made by Gitanjali G. (2017: 52) on Achebe's work:

He manages to manipulate the English language with the infusion of numerous Ibo legends, proverbs, riddles, moral tales and myths. But it is not merely a process of sprinkling a few proverbs and myths here and there; it is a much more complicated task. Through his language, Achebe attempts to capture the entire mental makeup of the African people, penetrate the past and give his readers the experience of the whole culture. Commenting on Achebe's use of language, Simon Gikandi says: -Although we read the world of the Igbo in English, Achebe goes out of his way to use figures of speech, most notably proverbs and sayings, to give readers a sense of how this culture might have represented itself to counter the highly regimented and stereotyped language of the colonizer. Thus Achebe tries to capture the psyche of his people, their emotions, aspirations, idealism and dilemmas by subverting the language and by making it say the African story from an African viewpoint. Bandia (2000: 267) seems to support this point of view when he says that:

Minority translating has the potential to significantly broaden the scope of research in translation studies as it opens up new approaches inspired by recent developments in other disciplines and discourses such as feminism, psychoanalysis, post-structuralism, post-colonialism and gay/lesbian studies. The interdisciplinary nature of minority translating research allows for the inclusion of other theoretical and political discourses which are likely to account for marginalized languages, literatures and cultures in translation studies.

The cultural aspects, in translation and by extension translation studies, are of paramount importance because they reflect people's worldviews. Let us take a basic example to explain the contours of worldview in this context. In the Western culture, when someone honours you or does something nice to you, you thank them by calling them or by sending e-mails, whereas in a typically African context, you have to thank them many times during several days. In the Ewe culture in West Africa, there is a courtesy modality called "sobedo" and "nisobedo". In accordance with this, when somebody does something important to you, you thank the person immediately as well as the following day and several days later. If you fail to give thanks several times during several days, your benefactor may be offended.

Another point made in Result 1 is that minor translating exposes the target culture to the influence of the source culture. This point has also been discussed by Bandia who has pointed out that:

For instance, Piotr Kwieciski's article shows how since the collapse of the socialist state in Poland the Polish language has succumbed to the global domination of English, absorbing Anglo-American items and resulting in the variation of standard Polish through translation. However, standard English is also varied or altered due to contact with Polish, resulting in a variety which is neither quite British nor American, but rather a Polish variety of English, hybridized through translation. (Ibid: 264)

Result 2 notes that the majority status of a language is determined by political, economic and cultural forces that are rarely static and therefore all languages are potentially minority languages. The fate of the Irish language after the Potato Crisis proved that a dominant language can become a minority language following social, economic and other changes. 
In Rwanda, for example, French used to be the majority or official language but it has become a minority language after the 1994 genocide when the new government decided to choose English as the new official language.

Result 3: Languages can be divided into target-language intensive and source-language intensive. Today English and translation are the two TL intensive languages in the world. The Translationum index published every year by UNESCO shows the target languages and the source languages. However, it is important to note that unlike Cronin, UNESCO and most other institutions and authors give the name target language to the language into which translation is done. A source language is a language from which translation is done.

Table 2: Translationum (2019)

\begin{tabular}{|c|c|c|c|c|c|c|c|c|}
\hline & $\begin{array}{l}\text { tatistics on whole Index } \\
\text { Translationum database }\end{array}$ & & \multicolumn{2}{|c|}{$\begin{array}{l}\text { Statistics on whole Index } \\
\text { Translationum database } \\
\begin{array}{|c|c|}\text { "TOP 50" Original } \\
\text { language }\end{array}\end{array}$} & & \multicolumn{3}{|c|}{$\begin{array}{l}\text { Statistics on Index Translationum } \\
\text { database for "Original language = } \\
\text { eng" }\end{array}$} \\
\hline 1 & German & 301935 & 1 & English & 1266110 & 1 & Germany & 173057 \\
\hline 2 & French & 240045 & 2 & French & 226123 & 2 & Spain & 121627 \\
\hline 3 & Spanish & 228559 & 3 & German & 208240 & 3 & France & 121443 \\
\hline 4 & English & 164509 & 4 & Russian & 103624 & 4 & Japan & 100552 \\
\hline 5 & Japanese & 130649 & 5 & Italian & 69555 & 5 & Netherlands & 63014 \\
\hline 6 & Dutch & 111270 & 6 & Spanish & 54588 & 6 & Sweden & 48941 \\
\hline 7 & Russian & 100806 & 7 & Swedish & 39984 & 7 & Poland & 45049 \\
\hline 8 & Portuguese & 78904 & 8 & Japanese & 29246 & 8 & Denmark & 41018 \\
\hline 9 & Polish & 76706 & 9 & Danish & 21252 & & China, People's & 40374 \\
\hline 10 & Swedish & 71209 & 10 & Latin & 19972 & & & \\
\hline & & & & & & 10 & Russian Federation & 40090 \\
\hline
\end{tabular}

Source: Index\%20Translationum_\%20UNESCO\%20Culture\%20Sector+++.html

These statistics show the dominant position of English as the source of most translations into German, French and Spanish. Another important remark on English is that it is the top original language in the world in terms of translation. It is followed by French, German and Russian, which are lagging far behind it. English-speaking countries are far from being top of the list of countries doing a lot of translation. Therefore, according to the terminology of UNESCO, English and French (to a lesser extent) are SL intensive languages.

Taking into account these statistics, it is obvious that translation is the yardstick by means of which a language can be classified as a minority or a majority language in the world at large. There is no denying that English is subjecting world languages to intertextual and stereotypical references. On this score, Cronin (Ibid: 96-97) has noted with concern that:

Reference material gives several on-screen pages to various US presidents but only two paragraphs to the European Community. The bulletin boards that can be accessed through the Internet are heavily dominated by American users as are the sites on the World-Wide Web. The translation takes place not only at the level of orthography and idiom but also at the level of intertextuality in view of the strong cultural bias in intertextual resources available either on CD's or on the Internet.

Result 4: Another factor that informs the relational position of minority languages is the fact that it is precisely the pressure to translate that is a central rather than a peripheral aspect of experience. Many TL intensive languages are most probably minority languages. Cronin (1995: 86) notes that "The third factor that informs the position of a minority language is the pressure to translate." This result confirms the role of yardstick played by translation in the era of globalisation. Translation is no longer a luxury that only rich countries can afford; it is a necessity if at all a country wishes to transact business with the rest of the world and remain afloat. Unfortunately many countries are still residing on the periphery of international communication and scientific and technical knowledge due to their lack of access to English and to a few dominant languages.

Result 5: Major language culture is informed by the minority language in translation (e.g. in the area of song, modes of intention, semantic fields, national identity). This aspect of translation has been echoed by several authors including Susan Bassnett who has spoken of the "cultural turn" in Translation Studies. This concept is presented in the book as a major trend in translation studies in 1990s. Bandia (op. cit.: 267) also says that: 
Indeed, disciplines such as sociolinguistics, discourse analysis and pragmatics have made inroads into translation studies and have shifted the focus from studying mainly standard varieties to studying non-standard, or marginalized, language cultures. These new approaches which thrive on their quest for understanding linguistic and cultural differences, seem better equipped to study peripheral or minority situations. (p. 267)

An example of information brought by a minority language can be found in Central Africa where Chibemba, a Bantu language, provides an interesting perspective on time and tenses. As studied by John Saeed (2000) in Semantics, Chibemba has more than three blocks of tenses. For example, there are several kinds of past: an immediate past (possibly less than an hour ago); a distant past (yesterday) and a remote past (more than 24 hours ago). Interestingly enough there is a time marker for each of these past tenses. This is a novelty in English and French linguistics. The translation of such a rich temporal system demands a reflection on current universalising linguistic principles established by Westerners. It is high time translation theory took cognisance of the wealth of knowledge and experience available in minority languages and cultures overseas.

Result 6: Translation theory itself remains hostage to the perceptions and interests of major languages.

The theory of translation is currently based on the experience of European languages but this model is not a "one size fits all" model that can aptly be applied to all languages all over the world. On this particular issue, a point made by Bandia is a wake up call:

Translation studies has been identified for a long time with majoritarian approaches whose objectives have been to establish scientific models based on universalizing theories. Universalizing theories are not inherently flawed insofar as they have provided the tools for a formal analysis of language and textuality. However, as Venuti points out in his introduction to this volume, "any effort to specify the minor situation requires that such tools be accompanied by the reconstruction of cultural and political contexts and a revision of universalizing theoretical concepts" (Ibid: 267

Result 7: The information and communication technologies are changing the definition of minority languages by favouring the development of new linguistic varieties. A case in point is e-Arabic. The information and communication technologies, especially Internet, have contributed to the emergence of a new dialect in Arab countries, which is called e-Arabic. In describing the language of the youth in Arab countries, Anissa Daoudi has explained that Internet has made it possible for the youth to develop a new dialect that breaks with established linguistic and cultural standards. Her discussion is based on the English translation of two novels written in eArabic, a new dialect that is a mixture of Latin expressions as well as foreign cultural features and Arabic words. It is indeed groundbreaking because nothing like that has ever been seen before. This new development proves that dialects may constantly be born and take different forms at different times. The translation of this new dialect poses problems in terms of lexicon as well as style and cultural references. Commenting on this phenomenon, Federici (2011: 476-478) has said that:

El volumen se cierra con la contribución de Anissa Daoudi sobre el estudio de una variedad árabe que la propia autora ha denominado como e-Arabic (e-arabe). Esta variedad lingüística está influenciada por el uso de las nuevas tecnologías (sobre todo, de Internet) y es característica de la juventud árabe y de los grupos sociales minoritarios que pretenden romper con las normas establecidas. Daoudi analiza, sin perder nunca de vista el factor cultural e ideológico, dos novelas en e-Arabic (y su traducción al inglés) que han suscitado grandes controversias en mundo árabe al transgredir los esquemas sociales y culturales establecidos con respecto al sexo y la religión, principalmente, y por emplear un lenguaje donde se encuentran latinismos y otros signos que denotan apertura cultural. La autora observa cómo las traducciones al inglés utilizan la variedad estándar y pierden, una vez más, toda la carga cultural del texto original.

It is obvious that Internet has been changing the worldview of the young generations of Arabs by exposing them to global cultures and values. All these are reflected in the concept of e-Arabic, which is a linguistic variety by a minority group. This ICT-assisted linguistic variety is a new sociolinguistic phenomenon.

Research result 8: No conformity of some literary productions with grammatical and academic standards due to a new sociolinguistic phenomenon that Apollinaire Agbazaou calls "nationalisme glottocentrique". In explaining this concept, the latter quotes Delas:

Daniel Delas appelle une abolition du contrôle logico-grammatical de la norme académique sur l'écrit littéraire. Autant d'indices qui autorisent à conclure que l'écriture de Barnabe-Akayi manifeste un nationalisme glottocentrique car le langage dont procède sa plume se refuse d'être un simple véhicule de la pensée, mais une représentation symbolique chargée de valeurs. $(2016: 214)$ One of the characteristics of this new phenomenon is 'hétérolinguisme', i.e. the use of foreign words and idioms in a text. There is also a phenomenon that consists in giving a new meaning to French words and most of the time this new meaning is just a literal translation of local language words into French. The following are a few examples: 
C'est incroyable. Quel que soit là où je reste, Edmonde c'est le nom de la fille qui est là avant mon arrivée, elle me dit : ne reste pas là ; Tantie va parler. Je me mets derrière le comptoir, elle me dit : ne reste pas là ; Tantie va parler. Je me déplace devant et me tiens debout, elle me dit : ne reste pas là ; Tantie va parler ! Je suis désorientée (2015 : 101) Actually “Tantie va parler' means 'auntie will shout at you' or 'she will reprimand' you' if you stand there.

In this second example, a local expression is translated literally into French in a way that somebody who does not understand the local fon language cannot comprehend. "A la télé, une croix noire dans un angle de l'écran. Qui est parti à Allada ? (...) Je revois l'écran, dans le même angle, outre la croix : François Mensah ! Paraît que André Dossa a pleuré comme un nouveau-né. (...) Christian Adandédjan, lui, a fait le garçon. (Ibid : 13)

In the local fon language, when somebody dies, people say that s/he has gone to Allada. There is another expression which means to be angry and it appears on page 26 in the novel. "Si c'est pas Joseph et ma jeune sœur Sabine qui parfois m'amènent à manger le fil (...) je me fâche guère'". In these last examples, a local expression meaning to be fond of somebody is translated literally as follows: "Personne n'ignore plus le fait que je suis morte pour vous." (Ibid: 175) On page 116, there is another expression translated literally: "Hier j'ai ri fata. J'ai ri fatiguée", which means that 'I have laughed a lot' or 'I have laughed so much that I was tired.'

This is colloquial language used by young people in urban areas who refuse to take themselves too serious. They do not use these words and expressions because they ignore the right French words and expressions. Actually they refuse to be academically correct. This new literary discourse is becoming a trend as witnessed by the language used in Temps de chien by the Cameroonian novelist Patrice Nganang. The use of the verb 'tenir' and of other lexical items coined on the basis of this verb is colloquial. The following is an excerpt from the text: «Les hommes riaient de ses ordres vite ressassés quand sa maîtresse était apparue, de son sourire colgaté devant le visage de celle qui « le tenait par le petit doigt ». (...) " Je vous dis qu'elle le tient, dites donc. » (...) "Laissez-moi vous dire. Le tiennement-là [sic] va finir demain. » $(1999: 84)$

On page 88, the new word coupement is coined and the narrator says "je vais la dormir" instead of "je vais coucher avec elle". Biloa (op. cit.: 111-112) has also noted that new words coined in tropical countries "mistreat" the French language. Par exemple, chez Sony Labou Tansi, les tropicalités comme néologismes maltraitent la langue

française (exemples : excellentiel, regardoir, gestées, dévirginisation, les pas toutà-fait, les près de mourir, les hommes bouts de bois, les hommes bouts de terre, chair-mots de passe, loque mère, ses trois ans d'eau dans la vessie, infernalement, des à-fusiller, pistolétographes, ancien vivant, garde-culs...) Georges Ngal montre que Sony Labou Tansi mélange plusieurs niveaux de langue (soutenue, familière) et qu'il a recours aux africanismes tels que recevoir une gifle intérieure, dormir une femme, les femmes s'appelaient bureaux, la plus tropicale énergie,

souris-sonner, tu peux vivre deux cents saisons de pluies, regardoirs, regardeurs, qui remet à demain trouve hier en chemin. On peut aisément se rendre compte que Sony Labou Tansi, à l'instar d'autres écrivains africains, use et abuse de la néologie lexicale et sémantique, telle que théorisée par Louis Guilbert (1975)

\section{Conclusion}

Minority languages and linguistic varieties are of interest to translation. Actually no language is essentially a minority language. Minority is the expression of a power relation between languages. Every language can become a minority/majority language following a change in socioeconomic and political circumstances. In Ireland, for example, English was a minority language but today it has become the majority language. Linguistic varieties submit the majority language to variations. Pidgin language in Nigeria, for example, is a variety of English with a mixture of local language words. The way the French language is mixed with local words in francophone novels and the various examples of coinage found in francophone literary discourse attests that no encounter between two people and languages is perfect. The French used by African novelists is just like an intra-lingual translation of the language.

The new information and communication technologies and the youth in a situation of diglossia are favouring the development of linguistic varieties which become very difficult to translate. These are encoded languages that only those who understand all the languages they are made up of can translate. This new phenomenon poses a challenge to translators who need to be more familiar with issues related to sociology and cultural realities. Translation theory needs to open up to new languages and cultures to tap the information and the wealth of knowledge that is available in these languages. The dominant position of English today is both an opportunity and a threat to the survival of peripheral languages. These peripheral languages are exposed to a lot of translated materials and information coming from English. Translators let in their native languages new foreign words and expressions which may threaten the originality and authenticity of their native languages in future. The world's linguistic ecosystem is threatened. 
Equality important in this debate is the question of intertextuality and over-representation of alien references in local languages all over the world. Semantics is another issue of concern in this debate. In other parts of the world, French and English words are given new meanings that are different from their original meanings. This is a serious matter of concern. Maybe the French not only need a French Academy but also a French language gendarmerie that will denounce and condemn serious semantic deviations. At the same time, there is a need to periodically take stock of new words and expressions entering the French and English languages in various parts of the world in order to validate some of them and to reject others. A linguistic policy bringing together speakers of each of these two languages all over the world should be the order of the day.

\section{Bibliography}

Agbazahou, A. (2016). Daté Atavito Barnabé-Akayi - Des horizons osés et contagieux, Editions LAHA

Bandia, P. (2000). "Compte rendu de [Lawrence Venuti (Guest Editor). Translation and Minority, special issue.” In The Translator. Studies in Intercultural Communication. Volume 4, Number 2, 1998.] TTR, 13 (2), 264 268.

Barnabe-Akayi D. A. (2015). Errance chenille de mon cœur, Plumes, Soleil, Cotonou, 196 p.

Bassnett, S. (2000). Translation Studies, Third Edition, Taylor \& Francis, UK

BILOA, E. (2006). « Appropriation, déconstruction du français et insécurité linguistique dans la littérature africaine d'expression française ». In Synergies Afrique Centrale et de l'Ouest, N²2 2007, pp. 109-126.

Chevrier, J. (1999). Littératures d'Afrique noire de langue française. Paris, Nathan Université.

Chinua, A. (1994). Things Fall Apart. First Anchor Books Edition, New York

Cronin, M. (1995). Altered States: Translation and Minority Languages. TTR, 8 (1), 85-103.

Dubois J., Giacomo M. et al. (2002). Dictionnaire de linguistique, Larousse-Bordas, Paris, pp. 435-436

Dumont, P. (2001). « L'insécurité linguistique, moteur de la création littéraire : merci, Ahmadou Kourouma ». In Diversité culturelle et linguistique : quelles normes pour le français?. IXe sommet de la Francophonie, Beyrouth 2001, Agence Universitaire de la Francophonie, pp.115-121.

Federici, Federico M. (2011): Translating Dialects and Languages of Minorities. Challenges and Solutions. Bern: Peter Lang, 233 p. Meta, 58 (2), 476-478.

Gitanjali G. (2017). "A Study on Chinua Achebe's Use of Proverbs in Things Fall Apart and No Longer at Ease." In IOSR Journal Of Humanities And Social Science (IOSR- $\quad$ JHSS) Volume 22, Issue 12, Ver. 7, PP 52-56

JACQUEMOND, R (1992). "Translation and Cultural Hegemony: The Case of French-Arabic Translation," pp. 139-158 in Lawrence Venuti, ed., Rethinking Translation. London, Routledge.

Kourouma, A. (1968). Les Soleils des indépendances, Paris, Editions du Seuil.

-(1990), Monnè, outrages et défis, Paris, Editions du Seuil

-(1998), En attendant le vote des bêtes sauvages, Paris, Editions du Seuil.

-(2000), Allah n'est pas obligé, Paris, Editions du Seuil.

Labou T. S. (1979). La Vie et demie. Paris, Editions du Seuil.

Lane P., Costa J. and De Korne H. (2018). "Standardizing Minority Languages". In Routledge Critical Studies in Multilingualism, pp. 1-23 ( $1^{\text {st }}$ ed). Routledge, New York.

Ngal, G. (1994). Création et rupture en littérature africaine. Paris, L’Harmattan.

Nganang P. (1999). Temps de chien, Le Serpent à Plumes, Paris, 369 p. Ngandu N. P. (1989). Ecritures et discours littéraires. Etudes sur le roman africain, Paris, L'Harmattan.

Ó SÉAGHDHA, Barra (1993). "The Tasks of the Translator," The Irish Review, 14, pp. 143-147.

Saeed, J.I. (ed.) 2000. Semantics - Third Edition printed in Singapore by Utopia Press Ltd. Venuti L. (1992). Rethinking Translation. London, Routledge. 